\title{
Seasonal variation in plasma concentrations of prolactin in castrated rams of breeds of sheep with different seasonality of reproduction
}

\author{
W. R. Carr and R. B. Land \\ A.R.C. Animal Breeding Research Organisation, Field Laboratory, Roslin, \\ Midlothian EH25 9PS, U.K.
}

\begin{abstract}
Summary. Finnish Landrace, Scottish Blackface and Tasmanian Merino rams were castrated and bled twice weekly from March to September. The breeds have widely different timing of seasonal variation in reproductive activity, but the plasma prolactin concentrations rose and fell at the same time in all 3 breeds, i.e. at the end of March and in September respectively. It is suggested that, even if major seasonal variations on plasma prolactin refiect primary changes in hypothalamic activity, these changes are modified by other factors to control the seasonal variation which occurs in the reproduction of the sheep.
\end{abstract}

\section{Introduction}

Breeds of sheep may differ markedly in the incidence of ovulation throughout the year (see Thimonier \& Mauléon, 1969; Land, Pelletier, Thimonier \& Mauléon, 1973; Wheeler \& Land, 1977). A considerable proportion of the variation in the time of onset of the breeding season within a population may be of genetic origin; in a flock of Welsh Mountain sheep, for example, the proportion has been estimated to be 0.35 (Purser, 1973). The opportunity for genetic selection for the duration of the breeding season is, however, restricted by the present inability to measure the trait in males, but there is evidence to suggest that this might be possible.

Genetic covariance between seasonal changes in testicular size and seasonal changes in the incidence of ovulation has been reported (Islam \& Land, 1977) but testicular size may also be genetically related to the number of eggs shed (Land \& Carr, 1975). Another possible criterion of seasonality is the concentration of prolactin in the peripheral blood, because hyperprolactinaemia is a characteristic of rams during the non-breeding season (Ravault, 1976) and of anoestrous ewes (Walton, McNeilly, McNeilly \& Cunningham, 1977). However, the presence or extent of causative relationships between the seasonal variation in reproduction and the concentration of prolactin is not known. Hyperprolactinaemia induced by TSH-RH reduced the sensitivity of the discharge of luteinizing hormone (LH) in response to oestrogen during the breeding season (Kann, Martinet \& Schirar, 1978) but the reduction of the concentration of plasma prolactin with bromocriptine did not increase this sensitivity (Land, Carr, McNeilly \& Preece, 1980).

It was therefore decided to study the association between the concentration of plasma prolactin and season in rams of breeds which differ markedly in the seasonal timing of their reproductive activity. Studies in which the duration of the photoperiod was reduced to 6 months have shown that gonadal steroids do not affect the timing of the prolactin response to changes in 
the photoperiod in Ile-de-France rams (Pelletier, 1973), but the genotype of the sheep is known to affect the influence of steroids on reproduction (Land, 1976). Castrated rams were therefore chosen to ensure that the present comparisons referred to a common base and intrinsic changes in the concentration of plasma prolactin could be measured; criteria for genetic selection among young males must be independent of aduit gonadal function.

\section{Materials and Methods}

\section{Animals and sampling}

Sheep of Scottish Blackface (Blackface), Finnish Landrace (Finn) and Tasmanian Merino (Merino) breeds were chosen. These have been shown to have quite different ovulatory seasons in Scotland (Wheeler \& Land, 1977). The Merino breeding season starts at the end of July, and the season for Finn and Blackface sheep starts simultaneously 6 weeks later, in late September. At the end of the season, the Blackface and Merino continue to ovulate until the beginning of March, whereas the Finn continue until mid-May, i.e. 11 weeks later. Equally, testicular size starts to increase approximately 8 weeks earlier in the Merino male than in the Finn male (Islam \& Land, 1977).

Seven mature males of each breed were bilaterally castrated before or during the period November 1974 to January 1975, when they were between 1 and 4 years of age. They were housed from that time under natural lighting conditions and penned in groups of 3-4. The sheep were handled regularly to familiarize them with all procedures before the start of the experiment.

Peripheral blood of each ram was sampled twice weekly with 3 or 4 days between samples by jugular venepuncture into evacuated heparinized tubes. The plasma was removed by centrifugation shortly after collection and stored at $-20^{\circ} \mathrm{C}$ until assay. Samples collected during the week beginning $8 \mathrm{March}$ to that of 15 September inclusive were assayed for prolactin. Potencies were transformed to natural logarithms to reduce the dependency of the variance on the mean. To simplify graphical display, the mean of the concentration in the 2 samples taken in each week was used to give a value for an animal for that week, except when individual samples were lost; then the remaining sample was used alone.

\section{Prolactin assay}

The plasma prolactin concentrations were determined by a double-antibody radioimmunoassay (McNeilly \& Andrews, 1974), using NIH-P-S6 as standard. The plasma samples were assayed in order of collection, with some plasma samples from the previous assay always included in the next assay. A control pooled ram plasma sample, tested in each assay, was used to establish between- and within-assay variation as coefficient of variation. The estimate for within-assay variation was $3.4 \%$ and for between assay variation $7.25 \%$ (mean concentration $=43.45 \mathrm{ng} / \mathrm{ml})$.

\section{Results}

The mean weekly plasma prolactin concentrations ( \pm s.e.m.) for each breed are shown in Text-figs $1(\mathrm{a}-\mathrm{c})$ for the period of the trial, together with the expected anovulatory periods of females and the time of onset of testicular growth for males of the Finn and Merino breeds. Also shown in Text-fig. 1 are the dates of shearing for the different breeds. 

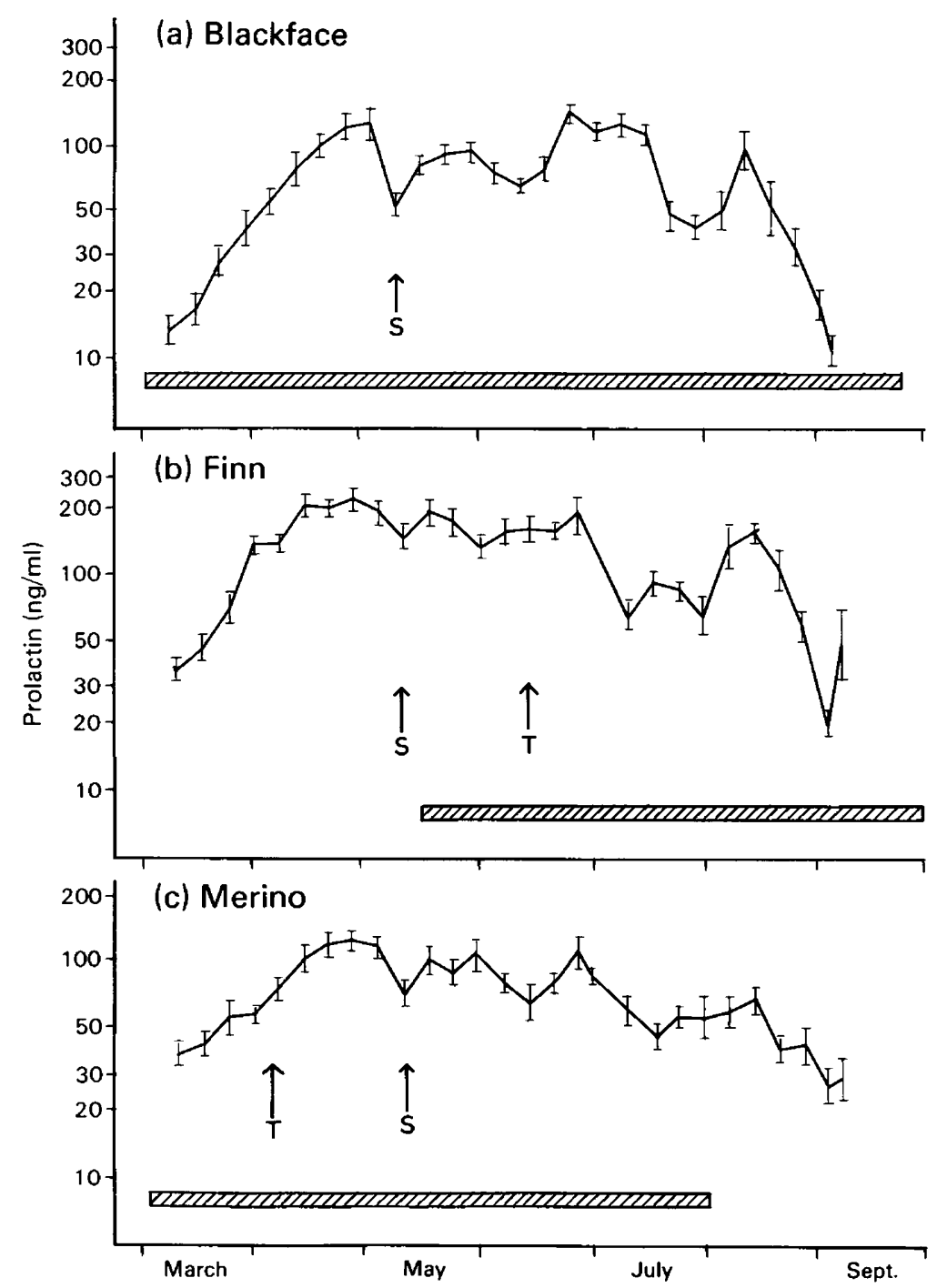

Text-fig. 1. The mean weekly plasma prolactin concentrations for (a) Scottish Blackface, (b) Finnish Landrace and (c) Tasmanian Merino sheep. S, time of shearing; T, time of onset of testicular growth in Finnish Landrace and Tasmanian Merino rams (Islam \& Land, 1977); hatched bars, duration of anovulatory period of females of all 3 breeds (Wheeler \& Land, 1977).

\section{Discussion}

The timing of the seasonal rise and fall in the concentration of prolactin in peripheral plasma was similar in the castrated rams of each of the three breeds studied, despite the marked differences in the timing and duration of the breeding season of these breeds. Prolactin concentrations rose in the Finns long before the expected time of onset of testicular growth (Islam \& Land, 1977) or seasonal anoestrus (Wheeler \& Land, 1977) for this breed. By contrast, the onset of testicular growth and of seasonal anoestrus in the Merino breed tended to coincide with the rise in the concentration of plasma prolactin, as did the expected time of onset of anoestrus in the Blackface 
(no data are available for seasonal variation in testicular size for this breed). Conversely, ovarian cyclicity would be expected to resume in the Merino before the concentration of prolactin reached basal levels. Only the results from the Blackface could have led to the postulate that the seasonal variation in reproduction in the sheep was closely related to seasonal variation of prolactin in peripheral plasma.

There is, then, no clear relationship between seasonal variation in the concentration of plasma prolactin in the present castrated males and the expected period of reproductive function. It is possible that feedback effects of gonadal hormones may modify hypothalamic activity so that the time of rise and fall in the concentration of prolactin is coincidental with the time of the end and the onset of reproductive function in the Finn and Merino breeds. Pelletier (1973), however, showed that neither the presence of testes nor the injection of testosterone influenced the effect of photoperiod on the concentration of plasma prolactin in Ile-de-France rams. Alternatively, the covariation between the concentration of prolactin in peripheral plasma and reproductive function, although normal in general terms, may be neither close nor obligatory. The independence of the two is supported by experiments in which daylength has been altered artificially. Howles, Webster \& Haynes (1980) reported continued cyclicity in the testicular diameter of rams in the absence of changes in the concentration of prolactin, and Thimonier, Ravault \& Ortavant (1978) demonstrated ovarian cyclicity in the presence of high prolactin concentrations, and vice versa. Studies by Walton, Evins, Fitzgerald \& Cunningham (1980) have also shown that plasma prolactin concentrations are much more sensitive to a change in daylength than is reproductive function in the female, so that the two become separated when daylength is suddenly reduced in mid-anoestrus. A further indication of the influence of environmental effects can be seen in the effect of shearing in the present experiments (Text-fig. 1); there was a marked lowering in plasma prolactin levels in all breeds. Ravault (1976) reported a similar effect with young rams, and maximum plasma prolactin concentrations at the time of the longest daylength.

The absence of covariation between seasonal variation in the concentration of prolactin and seasonal variation in reproductive activity indicates that, although the two may be generally related, genetic selection to alter the timing of seasonal changes in plasma prolactin would not be expected to lead to correlated changes in the time of onset and end of reproductive activity.

We thank Marjorie Fordyce, Mairwen Swaney, R. D. Preece and G. Baxter for expert technical help, Janet Foster for statistical help, the U.S. National Pituitary Agency and Dr A. S. $\mathrm{McNeilly}$ for provision of reagents.

\section{References}

Howles, C.M., Webster, G.M. \& Haynes, N.B. (1980) The effect of rearing under a long or short photoperiod on testis growth, plasma testosterone and prolactin concentrations, and the development of sexual behaviour in rams. J. Reprod. Fert. 60, 437-447.

Islam, A.B.M.M. \& Land, R.B. (1977) Seasonal variation in testis diameter and sperm output of rams of breeds of different prolificacy. Anim. Prod. 25, 311-317.

Kann, G., Martinet, J. \& Schirar, A. (1978) Hypothalamic-pituitary control during lactation in sheep. In Control of Ovulation, pp. 319-333. Eds D. B. Crighton, N. B. Haynes, G. R. Foxcroft \& G. E. Lamming. Butterworth, London.

Land, R.B. (1976) The sensitivity of the ovulation rate of Finnish Landrace and Blackface ewes to exogenous oestrogen. J. Reprod. Fert. 48, 217-218.
Land, R.B. \& Carr, W.R. (1975) Testis growth and plasma $\mathrm{LH}$ concentration following hemicastration and its relation with female prolificacy in sheep. $J$. Reprod. Fert. 45, 495-501.

Land, R.B., Pelletier, J., Thimonier, J. \& Mauléon, P. (1973) A quantitative study of genetic differences in the incidence of oestrus, ovulation and plasma luteinizing hormone concentration in the sheep. $J$. Endocr. 58, 305-317.

Land, R.B., Carr, W.R., McNeilly, A.S. \& Preece, R.D. (1980) Plasma FSH, LH, the positive feedback of oestrogen, ovulation and luteal function in the ewe given bromocriptine to suppress prolactin during seasonal anoestrus. J. Reprod. Fert. 59, 73-78.

McNeilly, A.S. \& Andrews, P. (1974) Purification and characterisation of caprine prolactin. J. Endocr. 60, 359-367. 
Pelletier, J. (1973) Evidence for photoperiodic control of prolactin release in rams. J. Reprod. Fert. 35, 143-147.

Purser, A.F. (1973) Variation in date of onset of the breeding season in sheep. Animal Breeding Research Organisation Report, H.M.S.O., pp. 24-30.

Ravault, J.P. (1976) Prolactin in the ram: seasonal variations in the concentration of blood plasma from birth until three years old. Acta endocr., Copenh. 83, $720-725$.

Thimonier, J. \& Mauléon, P. (1969) Variations saissonières du comportement d'oestrus et des activités ovarienne et hyphophysaire chez les ovins. Annls Biol. anim. Biochim. Biophys. 9, 233-250.

Thimonier, J., Ravault, J.P. \& Ortavant, R. (1978) Plasma prolactin variations and cyclic ovarian activity in ewes submitted to different light regimens. Annis Biol. anim. Biochim. Biophys. 18, 1229-1235.
Walton, J.S., McNeilly, J.R., McNeilly, A.S. \& Cunningham, F.J. (1977) Changes in concentrations of follicle stimulating hormone, luteinizing hormone, prolactin and progesterone in the plasma of ewes during the transition from anoestrus to breeding activity. J. Endocr. 75, 127-136.

Walton, J.S., Evins, J.D., Fitzgerald, B.P. \& Cunningham, F.J. (1980) Abrupt decrease in daylength and short term changes in the plasma concentrations of FSH, LH and prolactin in anoestrous ewes. $J$. Reprod. Fert. 59, 163-171.

Wheeler, A.G. \& Land, R.B. (1977) Seasonal variance in oestrus and ovarian activity of Finnish Landrace, Tasmanian Merino and Scottish Blackface ewes. Anim. Prod. 24, 363-376. 